\title{
Algunas reflexiones sobre las ermitas de la provincia de Sevilla y sus bienes muebles
}

\section{Juan Carlos Hernández Núñez}

Centro de Documentación del IAPH

\begin{abstract}
Hace exactamente dos años, en esta misma publicación, se dio a conocer uno de los proyectos del Programa de Protección del Plan General de Bienes Culturales, el "Inventario de bienes muebles de las ermitas de la provincia de Sevilla", realizado en 1989 I. En aquel momento y debido a la naturaleza de la sección del Boletín, "Servicios y productos", el objetivo era dar la noticia de que su contenido había sido vaciado en la base de datos de Bienes Muebles del Sistema de Información del Patrimonio Histórico Andaluz, (SIPHA). El motivo de retomar actualmente el tema no es otro que el incidir en la importancia, desconocimiento y la falta de protección de estos muebles e inmuebles. Después de algo más de diez años de la conclusión del trabajo, el conocimiento de este patrimonio sigue siendo el mismo. De hecho, apenas está estudiado, existiendo importantes lagunas en su conocimiento, tanto sobre la propia naturaleza de las ermitas y su origen, como sobre el ajuar mobiliario y litúrgico conservados en las mismas. Tales carencias hace que dicho patrimonio siga estando infravalorado $y$, en consecuencia, no se encuentre inscrito en los instrumentos de protección del Patrimonio Histórico español o andaluz. En aquella ocasión, faltó realizar una valoración profunda, desde el punto de vista del historiador del arte, de los objetos inventariados. No se pretende realizarla aquí, pues el análisis más profundo de este fenómeno, resulta una tarea más ambiciosa y compleja que sobrepasa con creces las disponibilidades de espacio de esta publicación. Por ello, solo se intenta realizar una primera aproximación, de carácter general, a esta tipología de templos y a sus bienes.
\end{abstract}

Antes de entrar directamente en el trabajo, es necesario efectuar una serie de precisiones para aclarar los conceptos y el origen sobre este tipo de inmuebles. Con el término de "ermita" se designa al "santuario o capilla, generalmente pequeña, situada por lo común en despoblado y que no suele tener culto permanente" 2 . Como se observa, en la definición se utilizan dos nuevos sustantivos, el de "santuario" y el de "capilla", correspondiendo cada uno de ellos a realidades distintas. El primero sirve para designar un lugar sagrado, ya sea iglesia, capilla o ermita, al que "por un motivo peculiar de piedad, acuden en peregrinación numerosos fieles", siempre con la aprobación del Ordinario del lugar3. La definición de la "capilla" no es tan fácil. El Derecho Canónigo actualmente vigente, se refiere solamente a las "capillas privadas" identificándolas como "un lugar destinado (exclusivamente) al culto divino con licencia del Ordinario del lugar, en beneficio de una o varias personas". El edificio puede no estar bendecido, aunque se recomienda hacerlo, siendo necesaria siempre la autorización del Ordinario para la celebración de la Misa y de otras funciones sagradas ${ }^{4}$. De forma genérica y conforme al uso de la costumbre, habría de entender la "capilla" como una iglesia pequeña que responde "al deseo de dar culto a los santos locales y universales de mayor devoción", siendo su uso público, en el sentido de que todos los fieles tienen derecho de entrar en las mismas para la celebración del culto divino ${ }^{5}$. En ellas, como en cualquier otro templo, se celebran diferentes ceremonias y ritos religiosos, excepto aquellos que sólo pueden realizarse en las iglesias parroquiales, como la administración de determinados sacramentos. Para la celebración de algunas de estas ceremonias en las capillas se necesita el permiso y consentimiento del Ordinario. Retomando lo anteriormente expuesto, se podría decir que las ermitas son capillas situadas en las afueras de las poblaciones. Sin embargo, con el desarrollo y el crecimiento de algunas poblaciones, dichos edificios han quedado integrados en los cascos urbanos, conservándose en estos casos el nombre de ermita como recuerdo de su antigua localización. Por otra parte, la definición de la Real Academia de la Lengua, sobre las ermitas se refiere al tamaño pequeño de dichas construcciones. Aunque esta característica se puede aplicar de forma genérica, habría que señalar la existencia de grandes edificios que se han ido configurando tras una serie de remodelaciones y ampliaciones a lo largo de su historia. Dichas transformaciones están relacionadas con el aumento del culto y la importancia que las imágenes titulares han adquirido a lo largo de la historia.

Si ésta es la definición actual de ermita, hasta hace poco más de doscientos años, ofrecía otro rasgo peculiar. Manteniendo las características actuales de ubicación en descampados y de recinto pequeño, su peculiaridad radicaba en la existencia de una habitación contigua en la que vivía el "ermitaño". Con este concepto queda recogida en el Diccionario de Autoridades, en su edición de 1737, "edificio pequeño a modo de capilla u oratorio, con su altar, en el qual suele haver un apartado o quarto para recogerse el que vive en ella y la cuida"6. Esta precisión, el de la existencia de "ermitaños", alude al origen de estas construcciones, al movimiento "eremítico" de los primeros años de la cristiandad y que tanta aceptación tuvo a lo largo de los siglos. Según San Isidoro, "los eremitas, también llamados «anacoretas», son los que han huido lejos de la presencia de los hombres, buscando yermo y las soledades desérticas"7. Una definición más clara sería, "todo individuo del clero secular o religioso o bien laico, de uno y otro sexo, que se retira por un tiempo considerable, separándose de la vida social y familiar, con la intención 

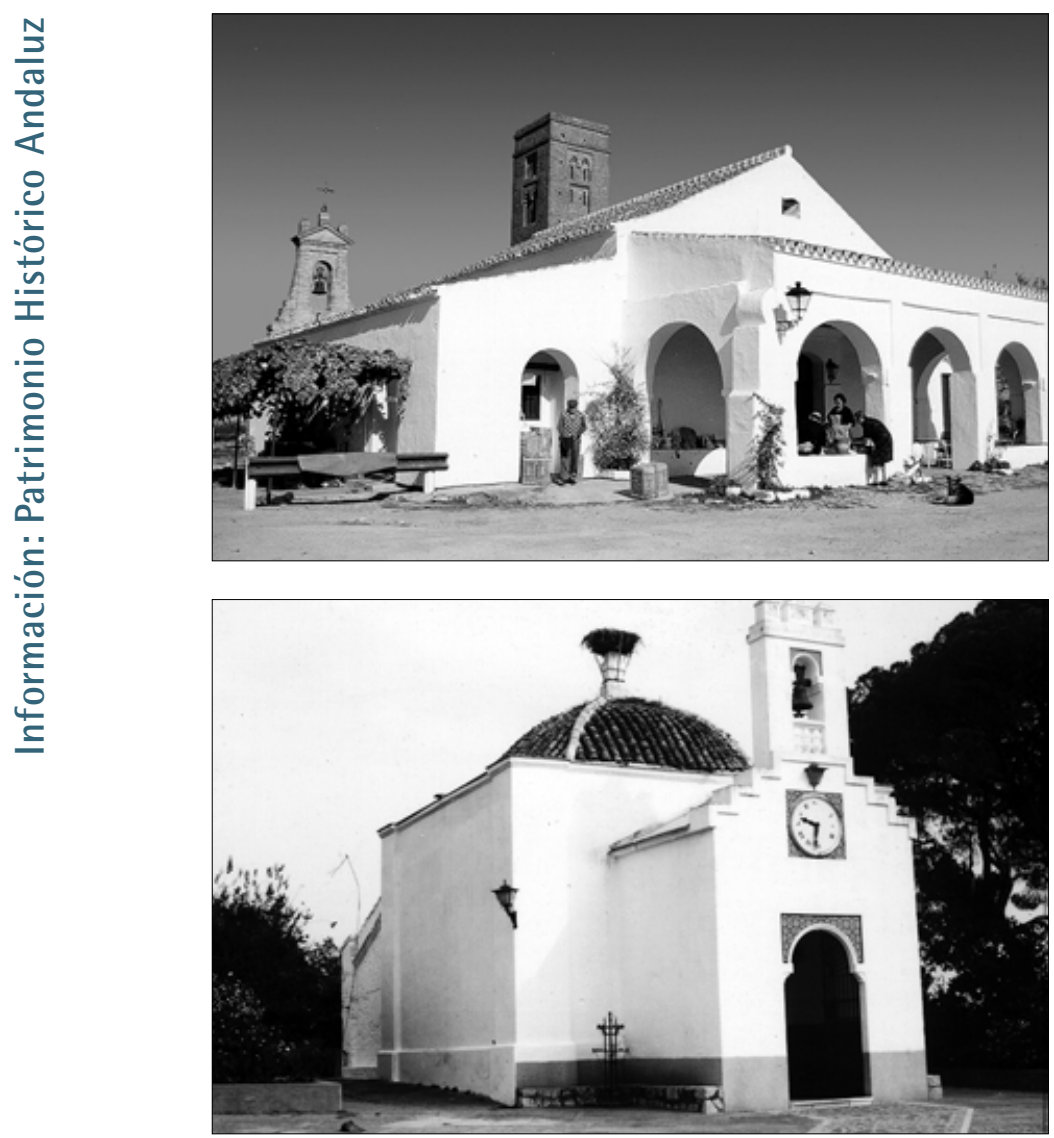

I. Bollullos de la Mitación. Ermita de Cuatrovitas.

2. El Ronquillo. Ermita de Nuestra Señora de Gracia.

3. Écija. Ermita de Nuestra Señora del Valle. Crucero.

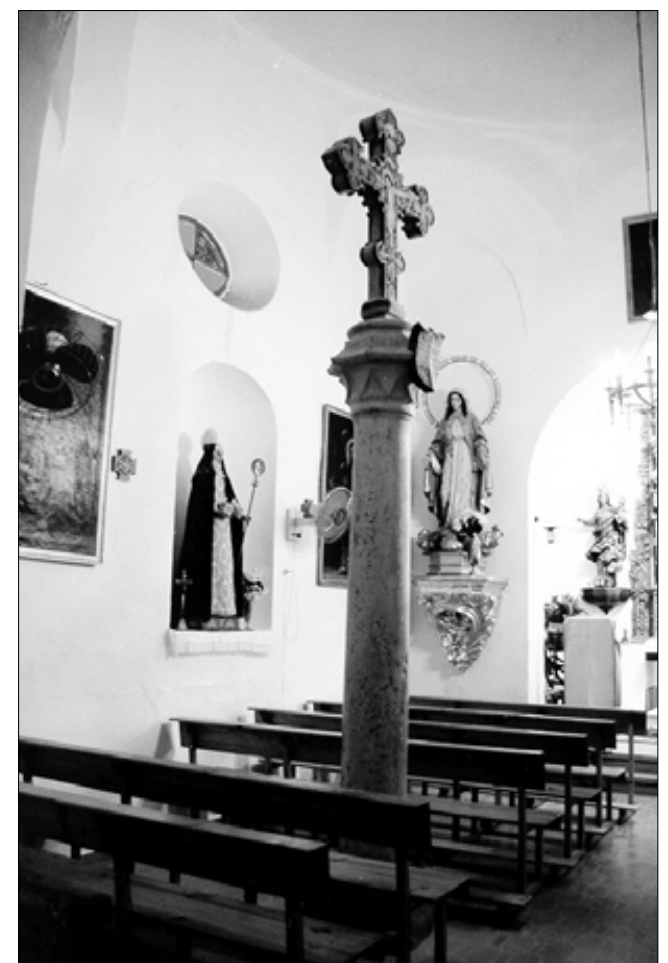

de hacer penitencia o de entregarse a la contemplación" 8 . Dichas personas construían pequeñas capillas, donde cultivar las necesidades de la vida espiritual, aprovechando en algunas ocasiones cuevas o salientes rocosos. Junto a ellas, se disponían los pequeños habitáculos en los que descansaban y hacían penitencia. En España se tienen noticias de eremitas desde el siglo IV y, a pesar de las prohibiciones y restricciones de esta forma de vida que irán imponiendo los monarcas y los papas, llegará hasta prácticamente el siglo XIX. Quizás un resto de ese "eremitismo", aunque con otros conceptos y planteamientos de vida, subsiste aún en los "santeros y santeras" que viven en las estancias adosadas a algunos de estos edificios.

El origen de las ermitas de Sevilla, al igual que sucede con las de otras poblaciones españolas, como las cordobesas, pudo estar ligado a la corriente espiritual que se desarrolla en época visigoda 9 . Faltan estudios que corroboren dicha hipótesis, aunque ciertas noticias atestiguan la existencia del movimiento "eremítico" en la provincia de Sevilla desde época antigua. Así, en el siglo VII, por la picaresca que se daba entre estos hombres solitarios, el obispo de Sevilla prohibió a sus religiosos esta vida de reclusión, porque "muchos (de ellos) se ocultan para ser mas conocidos y para que se ocupen de ellos"'10. Con ello también parece estar relacionado la publicación en Sevilla, en 1674, del libro de Fray Alonso de Santo Tomás Constituciones synodales del Obispado de Málaga , en el que se delimitan y fijan "tanto las normas de vida de los ermitaños de hábito o célibes como el culto y conservación de las fábricas" "I. Este modo de vida se perdería a lo largo del siglo XIX, quedando como únicos testimonios los edificios religiosos que han llegado hasta nosotros.

De los sesenta y seis inmuebles que se inventariaron en el trabajo antes citado, sólo son denominadas como ermitas treinta y nueve construcciones. El resto corresponden a once capillas y dieciséis iglesias parroquiales. No obstante, hay que señalar que algunas de las capillas inventariadas, como pueden ser la de Nuestra Señora de la Soledad en Gerena o la de Nuestra Señora de los Remedios en Los Palacios-Villafranca, eran primitivamente ermitas, de Santa Marta y de San Sebastián respectivamente, cambiando de tipología religiosa y de titularidad al ser ocupadas por Hermandades y Cofradías penitenciales. Tanto las capillas como las iglesias parroquiales son mucho más conocidas por el gran público, existiendo algunos estudios individuales, bien en monografías o en artículos de revistas, que tratan sobre sus historias y tradiciones, así como de los bienes que se guardan en su interior. Con respecto a los bienes muebles, ambas tipologías de templos, conservan un abundante patrimonio a pesar de los saqueos e incendios de la Guerra Civil 12. Ello es debido a su localización en el interior de las poblaciones y, en determinados casos, a la presencia de las hermandades y cofradías penitenciales que colaboran en el mantenimiento y ornato de los templos. Por el contrario, las ermitas, suelen ser menos conocidas y estudiadas, y, por regla general, los escasos bienes muebles que conservan son una mínima parte de los que tuvieron antaño.

La elección del lugar de construcción de estas capillas y ermitas está unida a hechos de carácter religioso o histórico. Entre los primeros, con una fuerte presencia de tradiciones y leyendas, se encuentran las edificaciones originadas por la localización de imágenes supuestamente escondidas durante la invasión musulmana. 
Puede servir de ejemplo la Ermita de Nuestra Señora de Gracia de Carmona, levantada en el lugar en que fue encontrada dicha imagen en el año 1290. En otras ocasiones, es el hallazgo del cuerpo incorrupto de un santo lo que dar lugar a una ermita como ocurrió con la Capilla de San Gregorio Osetano en Alcalá del Río. Curiosos resultan los ejemplos relacionados con apariciones de la Virgen. Este es el origen, en el siglo XVI, de la Ermita de Nuestra Señora de Gracia de El Ronquillo, debida a la aparición de la Virgen María, en lo alto de un olivo, a unos pastorcitos. Por eso, a la escultura, coetánea al milagro, se le añadió a principios del $X X$ el olivo y los pastorcitos arrodillados. Posiblemente, este cambio iconográfico se debió a la repercusión de las apariciones de Fátima y Lourdes y a los modelos de representación que ambas generaron. La Ermita de Nuestra Señora de Consolación de Carrión de los Céspedes puede servir como ejemplo de otro origen religioso, puesto que es el resultado de un milagro. De hecho, fue erigida en el mismo lugar en el que se atascó milagrosamente la carreta que portaba a la imagen titular. El escenario de un martirio sirve de asiento a la Ermita de Nuestra Señora del Valle de Écija. Fue levantada donde la tradición situó el tormento que padecieron las monjas del convento que regentaba Santa Florentina, hermana de San Isidoro y San Leandro. Recuerdo del mismo, se conservan en el templo, un simpático y populachero lienzo en el que se describe la escena y un crucero, erigido en el siglo XVI, que señalaba el lugar en el que se produjeron los hechos en el interior de la iglesia.

Algunos de estos acontecimientos tuvieron una enorme trascendencia posterior, sirviendo como núcleo de conventos o monasterios, haciéndose los religiosos cargo del culto y cuidado de las mismas. La ermita de Nuestra Señora de Gracia de Carmona, sirvió de cenobio, primero a los franciscanos, pasando posteriormente a posesión de los cistercienses y por último a los jerónimos. El actual edificio, solo conserva dos tramos de la nave de la iglesia, siendo los únicos testimonios del convento. Lo mismo sucedió con la ermita de Santa Ana de Osuna, aunque en este caso, al trasladarse las monjas al centro de la población, la capilla sirvió de enterramiento a los Figueroa. Esta familia construyó el edificio en el siglo XVIII que hoy sobrevive en medio de un polígono industrial. La Orden de San Francisco se dedicó a difundir el culto de la Veracruz, siendo las mayorías de las capillas y ermitas que tienen esta advocación los supervivientes a las leyes de desamortización y exclaustración del siglo XIX.

Un grupo importante, especialmente por las imágenes que en ellas se veneran, es el compuesto por los templos cuyo origen se relaciona con los hechos históricos de la Reconquista. El asedio de la ciudad de Sevilla por las tropas cristianas dio como resultado la construcción, en los lugares donde se habían instalado los campamentos, de las ermitas de Nuestra Señora de Valme en Dos Hermanas y Nuestra Señora del Aguila en Alcalá de Guadaira. Esta última se utilizó hasta mediados del siglo XVI como iglesia parroquial, pasando a denominarse ermita cuando la población abandonó definitivamente el recinto militar en el que se sitúa, a

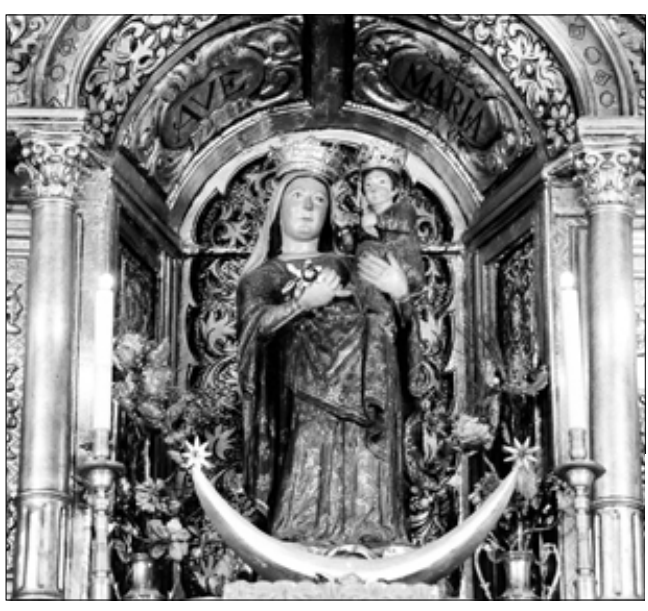

lo largo de la centuria siguiente. Relacionado con los capitanes del ejército de San Fernando, o con sus familiares, se encuentran la ermita de Nuestra Señora de Roncesvalles de Bollullos de la Mitación y la Capilla de Santa Ana de Dos Hermanas. En estos templos se veneran imágenes góticas, de fines del siglo XIII, excepto en la de Alcalá de Guadaira que, al ser quemada en 1936, fue sustituida por una copia realizada por Illanes al año siguiente. Aquellas esculturas son de gran interés, no sólo por ser las más antiguas que se conservan en la provincia, sino por tratarse de obras realizadas en talleres del norte de España o franceses, caso de la Virgen de Roncesvalles. Todas responden a los modelos medievales de tradición bizantina, apareciendo sentadas o de pie, sosteniendo al niño sobre el brazo o la pierna izquierda. Ambas figuras miran al frente, en actitud hierática, sin ninguna relación entre sí. Estas mismas características presenta la Santa Ana Triple de la capilla del mismo nombre en Dos Hermanas. En este caso, Santa Ana le sirve de trono a la Virgen y ésta, a su vez, al Niño. La iconografía de esta imagen es centroeuropea, siendo una simplificación de la representación del árbol de Jesse o generación terrenal de Cristo.

La ermita de San Mateo de Carmona, al igual que las anteriores, tiene su origen en la Reconquista. En este caso, en la acción de gracias por la toma de esta población sevillana el mismo día de la festividad del santo.

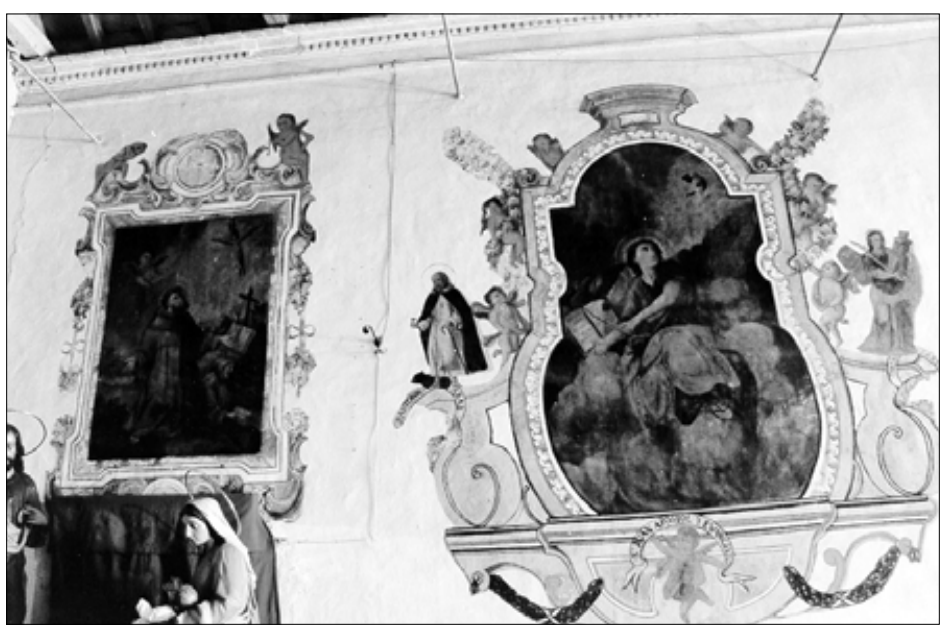

5. Puebla del Río Ermita de San Sebastián Pinturas murales. Detalle.
4. Ermita de Nuestra Señora de Roncesvalles. Virgen de Roncesvalles. 

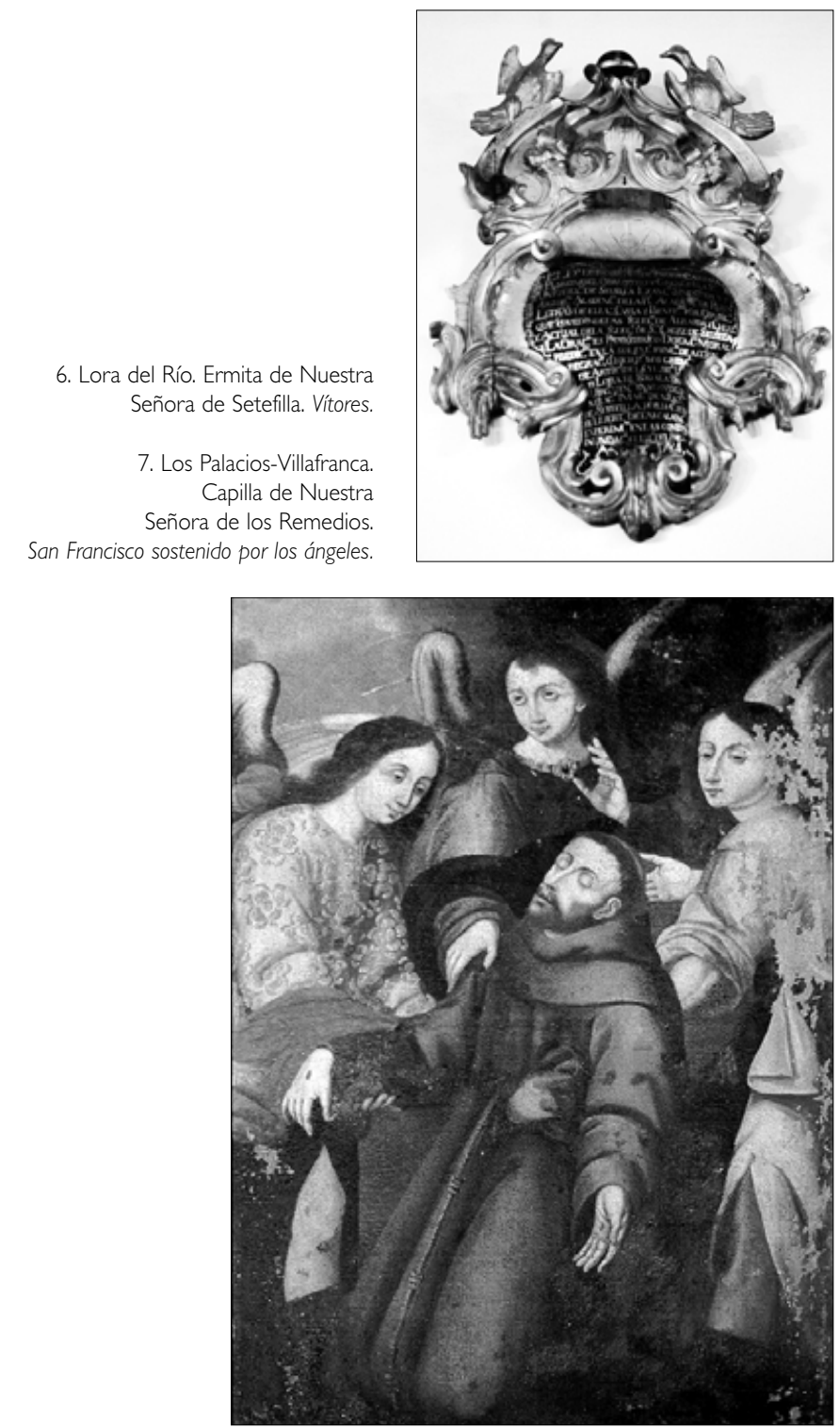

Los conquistadores decidieron construir una ermita donde celebrar los aniversarios a través de un acto de "pleito-homenaje" que, prácticamente, se estuvo realizando hasta mediados del siglo XIX. En la década de los ochenta del presente siglo, tras la restauración de la ermita, el Ayuntamiento ha recuperado esta antigua tradición ${ }^{13}$. Durante las obras de rehabilitación se descubrieron restos de pinturas murales, posiblemente del siglo XV. De entre ellas, la mejor conservada es la que representa, en el muro de la epístola, una Santa Lucía distinguiéndose sus atributos característicos, la bandeja con los ojos y parte de la palma del martirio.

Este hallazgo nos hace reflexionar sobre la importancia que tienen estos inmuebles para la Historia del Arte en Andalucía, ya que muchos de ellos guardan aún importantes obras pictóricas hasta hoy desconocidas. No es ésta la única muestra de pintura mural de fecha tan tardía que se ha localizado en la provincia de SeviIla. De no existir ningún testimonio medieval de esta modalidad de pintura, si exceptuamos las del Monasterio de San Isidoro del Campo en Santiponce, en los últimos años han ido apareciendo importantes testi- monios. Una vez estudiados y analizados en su conjunto, nos ayudarán a conocer mejor las labores de los talleres sevillanos a lo largo de los siglos XIII al XV. Junto a la anteriormente comentada y a las aparecidas, durante las obras de restauración, en la Capilla de la Magdalena del Conjunto Monumental de la Cartuja de Sevilla, habría que señalar las existentes en las ermitas de Cuatrovitas de Bollullos de la Mitación o, las recientemente restauradas, de Nuestra Señora del Águila de Alcalá de Guadaira. En aquella se han localizado diferentes restos, sobresaliendo el panel donde un grupo de personajes se distribuyen en un esquemático paisaje. En el de Nuestra Señora del Aguila figuran San Mateo y Santiago el Mayor, vestido éste de peregrino, cobijados por un arco apuntado y teniendo de fondo un falso tapiz decorado con motivos vegetales, inspirados en tejidos tardomedievales.

Junto a estas raras pinturas medievales, algunas ermitas conservan parte de su primitiva decoración mural realizada entre los siglos XVI y XVIII. En el lado de la epístola del presbiterio de la ermita de Nuestra Señora de Guía en Castilleja de la Cuesta se observa un fragmento de la pintura la Adoración de los Reyes del siglo XVI. Está cobijada bajo un arco de medio punto decorado con motivos vegetales, siendo visible parte de los tres magos. El único completo, viste túnica roja y manto marrón portando entre las manos un objeto. De los otros dos, en pié, solo se conserva parte del manto azul de uno y del tercero el calzón blanco y una túnica roja. En la misma ermita de Cuatrovitas existe también un San Cristóbal del siglo XVIII. Las paredes de la ermita de San Sebastián de Puebla del Río presentan un interesante programa iconográfico-devocional realizado en el último tercio del siglo XVIII, aún sin estudiar. Enmarcados por rocallas, guirnaldas y angelitos aparecen, en forma de cuadro o efigiados en cartelas, San Rafael, San Fernando, San Marcos, San Isidoro, San Cayetano, San Mateo, Santa Marina, San Antonio de Padua, San Francisco de Asís, San Antonio Abad, San Juan Evangelista, Santa Bárbara, San Joaquín, San Diego, Santa Isabel de Hungría, Santa Ana, San Basilio, San Lucas, Santo Tomás y San Juan Nepomuceno. Menos vistosos, pero no por ello menos importantes, son los conjuntos de la ermita de Guaditoca de Guadacanal, realizado por Juan Brieva, y el de la Iglesia de San Bartolomé de Cantillana. Escenas bíblicas, padres de la iglesia y evangelistas aparecen en la primera, mientras que ángeles pasionarios entre guirnaldas de flores, rocallas, cintas con versículos y cartelas de exaltación a la pasión de Cristo cubren las bóvedas de la segunda. Otro tipo de ornamentación de estos templos son las yeserías, aunque algunas de ellas, en el año 1989, se encontraban prácticamente perdidas por el hundimiento de las cubiertas, como las deciochescas de la ermita de la Virgen del Carmen en Pedrera. Otras, en cambio, han tenido una mayor fortuna. Así, en Lora del Río, las bóvedas de la ermita de Setefilla siguen conservando las labores de yeserías, de motivos vegetales enmarcadas en registros geométricos, de fines del siglo XVII.

Muchos de los bienes muebles existentes en estas capillas y ermitas, especialmente en las ubicadas a las 
afueras de las poblaciones, tal y como recomiendan las Autoridades Eclesiásticas, han sido trasladados a las iglesias parroquiales de las poblaciones por motivos de seguridad, devolviéndolos a sus respectivos templos durante la festividad de los titulares. Sería larga la lista de bienes que han sido trasladados, aunque en el caso de las imágenes titulares, algunas de ellas, el cambio de ubicación, está relacionado con epidemias y enfermedades que asolaron a las poblaciones a lo largo de la historia. La Virgen del Valme se llevó a la iglesia parroquial de Dos Hermanas para salvar a la población de una epidemia de peste acaecida hacia el 1800. En su lugar, en la ermita, actualmente existe una reproducción fotográfica. Un trampantojo del siglo XVIII preside el altar de la ermita de la Virgen de Gracia de Carmona, desde que a mediados del XIX la titular se depositó en la iglesia prioral de Santa María. Asimismo, un simpecado preside, desde hace pocos años, el retablo donde se situaba la Virgen de Cuatrovitas, tras su traslado a la parroquia de Bollullos de la Mitación.

Si esta medida es tomada para los objetos de gran valor histórico, artístico o devocional, no suele ser aplicada a los exvotos, a pesar de que son los únicos bienes muebles que aparecen explícitamente señalados en el Derecho Canónigo, prestando especial atención a su seguridad y al modo de exposición ${ }^{14}$. Este interés de la Iglesia por los exvotos radica en el hecho de ser actos de fe hacia la imagen, testimonios de la devoción y veneración que se tiene a las imágenes sagradas. Tal y como su nombre indica, estos objetos son ofrendas a la divinidad como resultado de una promesa o de un favor recibido. Los más interesantes, por su valor documental, son los que narran los milagros y las diferentes circunstancias por las que el beneficiario solicitó la intervención divina. Los inventariados en las ermitas sevillanas responden a esta tipología, encontrándose en las capillas de Nuestra Señora de los Remedios de El Coronil, de la Vera Cruz de Marchena, de San Gregorio Osetano de Alcalá del Río, de la Hacienda de Torrijos de Valencina de la Concepción y en las ermitas de Nuestra Señora de la Aurora de Los PalaciosVillafranca, de la Vera Cruz de Coria del Río y de Nuestra Señora de Setefilla en Lora del Río. Estos, generalmente rectangulares, están realizados con la técnica del óleo sobre lienzo y compartimentados en dos zonas bien diferenciadas. En la superior, se narra gráficamente el milagro, mientras que en la inferior, una leyenda sirve para identificar al autor de la súplica, así como los hechos ocurridos. Particularmente interesantes son los conservados en la Capilla de la Hacienda de Torrijos y en la Ermita de Nuestra Señora de Setefilla. En la primera, a pesar de ser un oratorio privado, la relación devocional con la población es bastante grande, especialmente durante los siglo XVIII y XIX. A estos siglos corresponden los cincuenta y nueve exvotos, siendo una de las colecciones más importantes y numerosas que se conservan en la provincia de Sevilla. En los mismos se efigia la escultura del Cristo de Torrijos, imagen de Cristo atado a la columna de fines del XVI. Acompañan a la imagen el gallo y la cabeza de San Pedro, a manera de atributos personales, símbolos de la negación de este Santo. En el segundo de los santuarios, el de Setefilla, junto a los numerosos

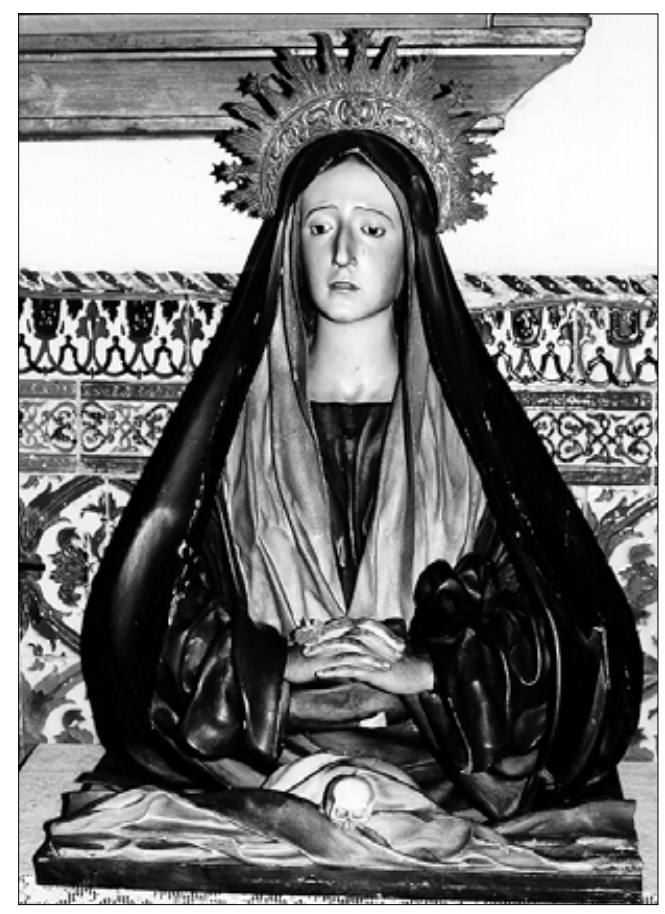

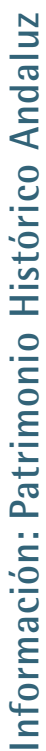

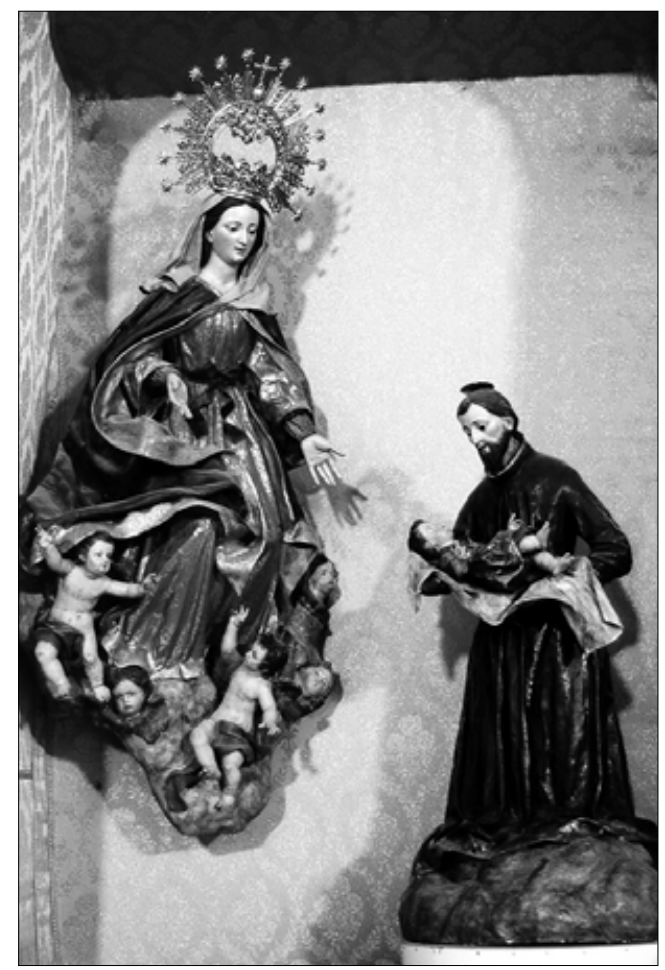

8. Valencina de la Concepción. Capilla de la Hacienda de Torrijos. Dolorosa.

9. El Saucejo. Iglesia parroquial de San Marcos. San Cayetano con la Virgen o Virgen de los Desamparados. exvotos, se conserva una peculiar colección de Vítores. Éstos, formados por inscripciones de diferentes formas y tamaños, son productos de una tradición local. Se realizan cuando la Virgen baja a la población, reclamada por los vecinos para pedir una gracia o agradecer los favores otorgados. La cronología de los mismos abarca desde el siglo XVIII hasta nuestros días.

El valor de Patrimonio Cultural que estos tienen es de gran importancia, ya que documentan actitudes, hechos y costumbres de las diferentes poblaciones. Al contrario de lo que se puede pensar, no sólo son trascendentales para el conocimiento de la ideología o de 


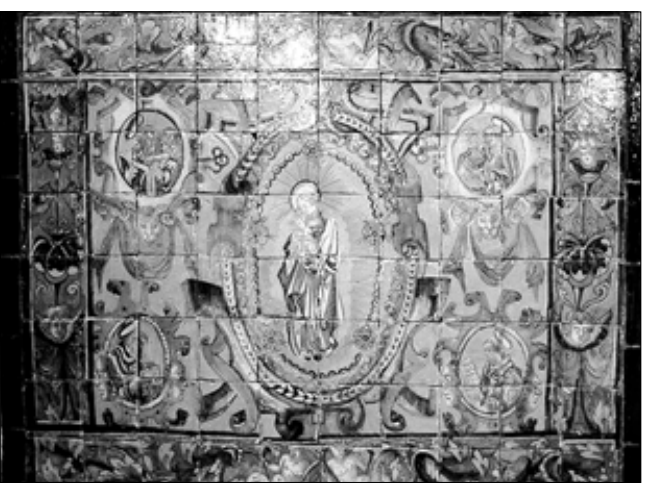

las creencias religiosas, sino también ofrecen una gran información sobre las actividades, costumbres y modos de vida. El interés que ha despertado este tema desde la década de los ochenta puede rastrearse a través de las exposiciones y publicaciones que se han realizado sobre los exvotos a partir de entonces ${ }^{15}$. Sin embargo, tanto en unos como en otros, los análisis que se realizan de tales bienes son generalmente desde el punto de vista de la antropología social, faltando en ellos otros estudios con planteamientos diferentes que complementen y permitan conocer en profundidad el fenómeno. Hay que considerar que el antropológico no es el único valor que poseen dichos bienes, ya que desde la perspectiva histórica o artística resultan, asimismo, documentos de gran utilidad. Una de las características que presentan estos bienes es la fidelidad de los anónimos autores al describir los fondos, ya sean éstos paisajes urbanos o rurales o interiores de viviendas. Más preocupados por lo anecdótico de la escena que por los propios actores, detallan minuciosamente aspectos urbanísticos o arquitectónicos, así como enseres y vestimentas. A través de ellos, pueden ser analizados estos factores, convirtiéndose en muchos casos en la única fuente de gráfica para el análisis de estas poblaciones. Esa fidelidad a la realidad también queda reflejada en la figuración de las imágenes sagradas. Estas aparecen con tal cantidad de detalles que poco se diferencian de las imágenes devocionales realizadas en lo que se ha venido a denominar el "arte culto". Gracias a ellos, es posible conocer aquellas esculturas o pinturas que se han perdido a lo largo del tiempo o las transformaciones sufridas en los adornos o en las maneras de ataviar a los santos o vírgenes. En ocasiones, a modo de trampantojos, detallan los altares o retablos en los que se veneran, pudiéndose seguir a través de los exvotos los cambios y reformas estéticas acaecidas en ellos.

No son éstos los únicos bienes muebles de interés histórico o artístico que se conservan en las ermitas y capillas sevillanas. Existe una interesante variedad de bienes muebles de los siglos XVI al XIX que, si bien tratar de todas ellos sería complicado, si sería oportuno el señalar algunos de los más importantes. Seguidoras de los modelos de las Vírgenes del grupo de la reconquista, pero ya del siglo XVI, serían la del Rosario de la Iglesia de San Miguel de Castilleja del Campo, la de la Huerta en la iglesia parroquial de Puebla de los Infantes y la de la Aurora de la ermita del mismo nombre en Fuentes de Andalucía. Otra imagen de la misma centuria es el grupo de la Piedad que se encuentra en el altar mayor de la ermita de Nuestra Señora de las Angustias en Alanís. En este caso, la Virgen sostiene en su regazo el cuerpo de Cristo muerto. Formaban parte de esta escena, producto de la sensibilidad patética de fines del medioevo, las dos imágenes de San Juan y la Magdalena, que hoy aparecen en las calles laterales del retablo. El grupo central ha perdido esas características tan peculiares de la escultura del primer tercio del siglo XVI, fecha en la que se data el conjunto, por haberse transformado la Virgen en una escultura de vestir y en una restauración realizada por Castillo Lastrucci en el presente siglo.

Al mismo siglo XVI pertenecen las esculturas de San Sebastián de la iglesia parroquial de Burguillos y, de fines de la centuria, la existente en la ermita de la misma advocación de Carmona. Un San Roque del círculo de Juan Bautista Vázquez el Viejo se localiza en la Capilla de Santa Ana de Dos Hermanas. En la Sacristía del mismo templo merece destacarse las dos puertas, con las pinturas de un seguidor de Alonso Vázquez, donde se representan a San Pedro y San Pablo con dos escenas del hallazgo de la imagen de Santa Ana por las Hermanas Nazarenas. Renacentista son también los crucificados de las ermitas de la Virgen del Espino de El Pedroso, el del Santo Cristo de la Sangre de Pedrera y el de la Vera Cruz de Coria del Río y los de las iglesias parroquiales de Martín de la Jara, Almadén de la Plata y Almensilla. Además de estas obras anónimas, con la misma advocación del Cristo de la Vera Cruz, existen dos ejemplos más relacionados con los seguidores de Roque Balduque, como son los crucificados de las capillas de San Gregorio Osetano de Alcalá del Río y de la Vera Cruz de Marchena, ambos de gran calidad artística. En esta última capilla se encuentran los restos de un retablo, hoy recompuesto con balaustres y los relieves de la decapitación de San Matías y Santa Bárbara, probablemente obra de Gaspar de Aguilar y fechado en I588. Este cobija un lienzo de Juan Bautista de Amiens, de principios de la centuria siguiente, en el que aparecen San Juan Bautista y San Vicente. El mismo pintor y para el mismo templo realizó en 1589 el lienzo de la Piedad y, algunos años más tarde, el de la Visitación con San Diego de Alcalá y Santa Catalina.

Son muy numerosos los bienes muebles de los siglos $\mathrm{XVII}$ al XIX que se conservan en las ermitas sevillanas. Algunos de ellos sorprenden por su calidad artística si se piensa en el carácter popular de estas construcciones. Quizás sería conveniente sacar del anonimato los grandes lienzos de la ermita de Nuestra Señora de la Aurora de Los Palacios-Villafranca de Los Desposorios de la Virgen y la Adoración de los pastores, obras de transición de los siglos XVII al XVIII. En la misma población y del siglo XVII, se encuentra el San Francisco sostenido por los ángeles o Éxtasis de San Francisco de la Capilla de Nuestra Señora de los Remedios y, a principios del siglo XVIII, fue realizado La entrega del rosario a Santa Rosa de Lima de la Iglesia de San Bartolomé de Cantillana. Entre las esculturas habría que llamar la atención sobre la Virgen de los Dolores de la capilla de Torrijos, de Valencina de la Concepción, o la 
existente en la iglesia de San Marcos de El Saucejo, de San Cayetano con la Virgen o Virgen de los Desamparados. La gran calidad de ambas esculturas hace pensar que corresponden a obras de los talleres de Pedro de Mena, la primera, y de Cristóbal Ramos, la segunda.

Obras sorprendentes son algunos de los retablos que se localizan en estos templos, producto de las remodelaciones que sufrieron durante los siglo XVII y XVIII. Entre los más interesantes del siglo XVII se encuentren los que ocupan los presbiterios de la Iglesia de San Benito, de Castilleja de Guzmán, los de las ermitas de Cuatrovitas, de Bollullos de la Mitación, con su frontal cerámico del siglo XVI, y el de la Virgen de Guaditoca, de Guadalcanal. Este último, recompuesto, sirve de embocadura al camarín de la virgen, que ocupa la calle central y se eleva por encima del primer cuerpo. Se compone de un alto banco sobre el que se levanta el único cuerpo con tres calles, enmarcándose las laterales por columnas entorchadas con capitel compuesto. En estas últimas se encuentran medios puntos para ser ocupados con lienzos, hoy desaparecidos, y sobre éstos, registros rectangulares con pinturas de santas mártires. Sobre las calles corre un friso que sirve de apoyo al basamento del ático, formado por volutas laterales y dos pequeños lienzos rectangulares con santos. En el ático aparecen tres lienzos, un Crucificado, al centro, y, en los laterales, San Joaquín y Santa Ana con la Virgen niña. Al siglo XVIII pertenecen, entre otros, los retablos mayores de las capillas de la Vera Cruz de Marchena, de la Virgen de Belén y de la ermita de la Aurora, ambas de Los Palacios-Villafranca, el de la Virgen de los Remedios de El Coronil y los de la Capilla de la Aurora, en Fuentes de Andalucía. En esta última ermita, el dedicado a San Francisco de Paula presenta como enmarque de la hornacina central dos ángeles atlantes. Por la delicadeza de la formas y lo ingenuo del lienzo que lo preside, habría que llamar la atención sobre el retablo-marco de las Ánimas, de la primera mitad del siglo, de la ermita de Belén en Lebrija. De la mayoría de estas obras se desconoce su autor, siendo en algunos casos atribuidos a seguidores de los diferentes maestros sevillanos. Este era el caso del retablo de la Capilla de Santa Ana de Dos Hermanas. La bibliografía tradicional lo atribuía al círculo de Fernando de Barahona. Sin embargo, las investigaciones realizadas en los últimos años han podido concretar que las trazas pertenecen a Juan de Valencia y las esculturas a Agustín de Perea 16.

Del siglo XIX existen interesantes ejemplos, a pesar de que siguen siendo poco valorados. Uno de los conjuntos más destacados por su uniformidad estilística es el que decora el presbiterio de la ermita de Nuestra Señora de la Soledad, de Cantillana. La construcción del templo fue concluida el 7 de diciembre de 1792, colocándose la imagen titular dos años más tarde. Tanto el retablo mayor como los enmarques de las puertas del presbiterio corresponden a esos años finales de la centuria. En ellos se utilizan como elementos de soporte columnas corintias de fustes acanalados y como motivos decorativos las guirnaldas, rocallas, roleos y jarrones. El retablo está compuesto de banco, un solo cuerpo de tres calles y ático. Las calles laterales son ocupadas por las esculturas de San Miguel y San José, mientras que en la central aparece una urna de remates curvos, con un Cristo yacente, y sobre ella el enmarque del camarín de la Virgen de la Soledad. Un relieve de la Santísima Trinidad preside el ático. Los enmarques de las puertas se flanquean por columnas, rematadas por un frontón partido y una ménsula al centro, a manera de clave. Sobre éstas aparecen las imágenes de Santa Rita, en el muro derecho, y San Sebastián, en el izquierdo, cobijados bajo un frontón circular.

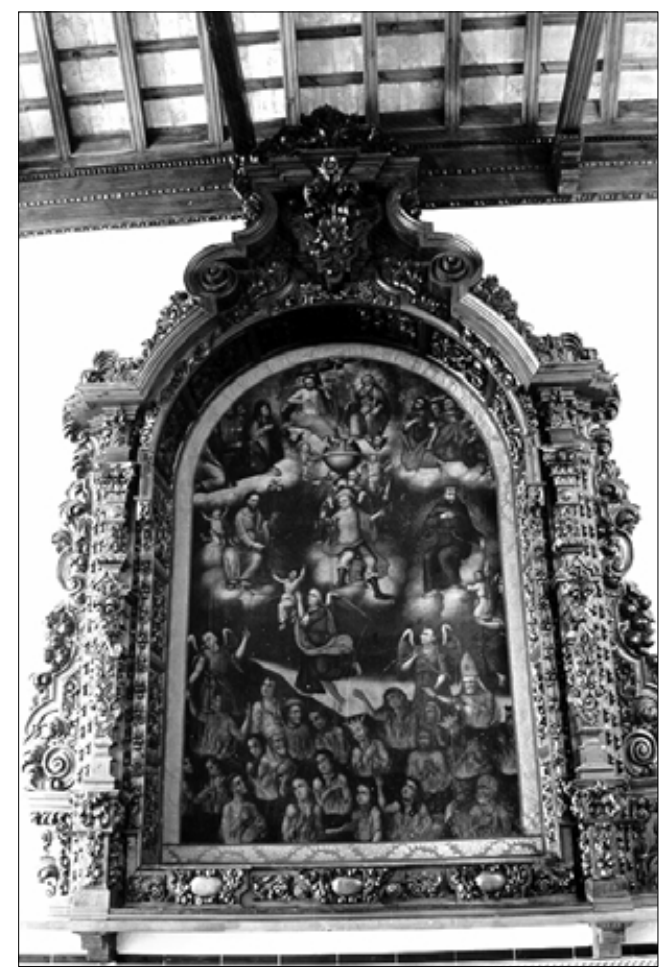

I I. Lebrija. Ermita de Nuestra Señora de Belen Retablo-marco de las Ánimas.
No todos los bienes que actualmente aparecen en estos edificios fueron realizados exprofeso para los mismos. Tras la desamortización de Mendizábal y sobre todo concluida la Guerra Civil, muchos de estos inmuebles son redecorados con bienes procedentes de otros templos de la provincia. A la iglesia de San Felipe de Carmona pertenecen los actuales retablos mayor y de la Divina Pastora de la ermita de Nuestra Señora de Gracia de Almadén de la Plata. Del antiguo convento de la Orden Menor de San Francisco de Estepa procede el retablo de la capilla del Rosario de El Rubio, del convento de la Asunción de Sevilla el de la ermita de Nuestra Señora de Belén de Pilas, de la iglesia de San Carlos el Real de Osuna el de la Iglesia de San Marcos de El Saucejo, o de una iglesia de La Rinconada el que preside la ermita de Nuestra Señora de Valme. Éste de fines del siglo XVIII presenta una curiosa decoración en su mesa de altar de escenas de inspiración japonesa. Además de los retablos también fueron trasladadas esculturas y pinturas, costumbre que ha llegado hasta nuestro días. El Cristo del Voto procedente de una iglesia de Carmona fue llevada a la iglesia de San Cristóbal de Burguillos o la Virgen de la Silla de la iglesia de San Luis se depositó en la capilla del Cristo de la Cárcel. Traslados mucho más modernos 


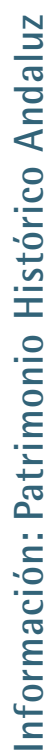

12. Albaida. Ermita de la Vera Cruz. Alegoría eucarística.

13. Cantillana. Capilla de Nuestra Señora de la Soledad. Puerta del presbiterio.
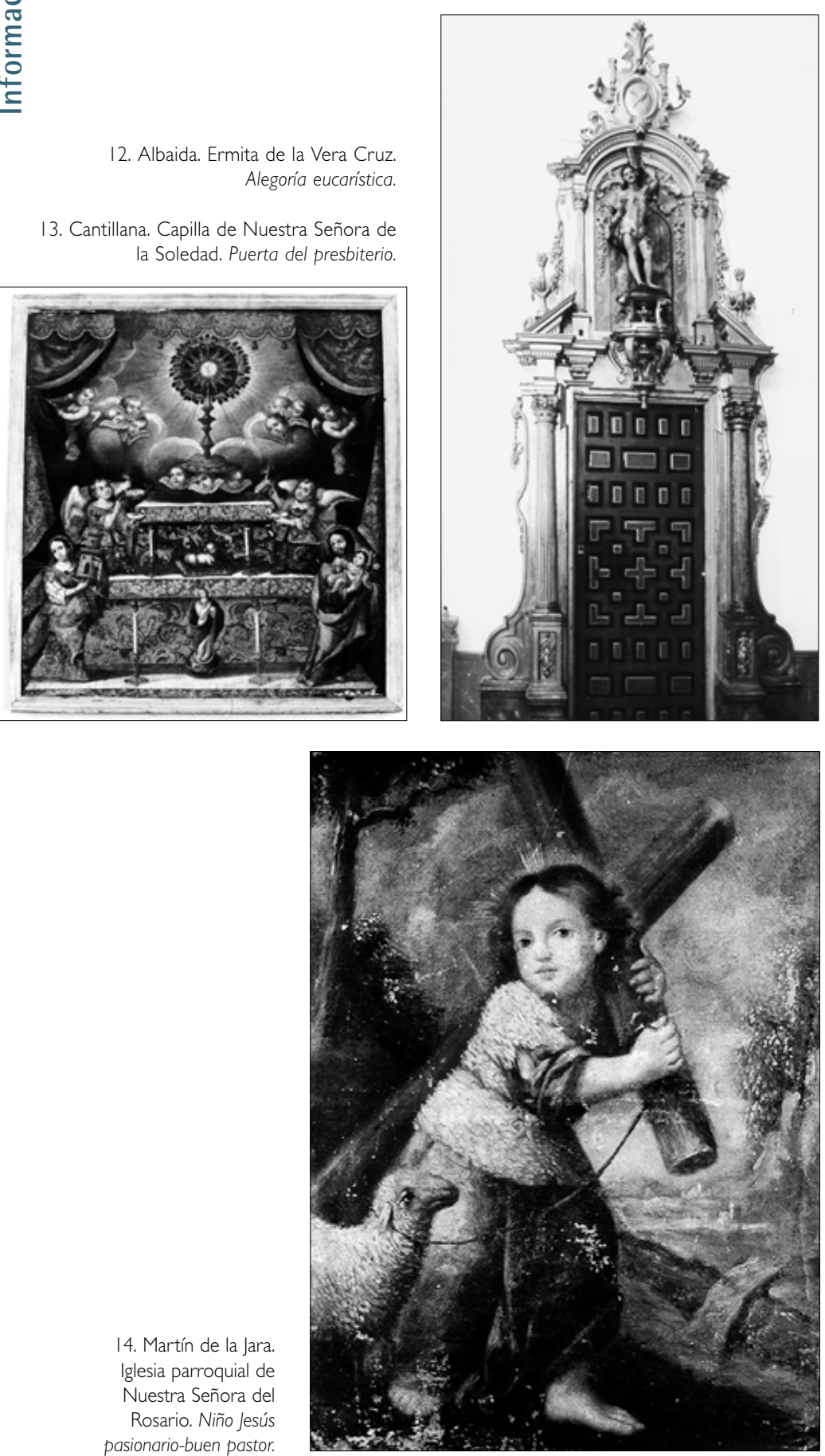

coronado por una cruz, enmarcado estos últimos por una corona de espinas. Sobre ésta, dos angelitos sujetan una corona con imperiales. En la Alegoría eucarística de la ermita de la Vera Cruz de Albaida, se representa un altar de dos cuerpos. Delante del primero se encuentran Santa Bárbara, una pequeña Inmaculada, al centro, y San José con el Niño. Sobre los santos, a los lados del segundo frontal, dos ángeles turiferarios, y ,en medio, el Cordero sobre el Libro de los Siete Sellos. Sobre el altar una custodia resplandeciente rodeada de cabezas de angelitos. Se enmarca la escena por dos cortinas que son recogidas en los laterales por dos ángeles. Un tercer ejemplo es la Alegoría eucarística de la ermita de Cuatrovitas de Bollullos de la Mitación. Sobre un altar se exhibe una gran custodia flanqueada por dos ángeles. Delante se sitúan los cinco Doctores de la Iglesia.

Junto a estas obras, no se pueden pasar por alto aquellas otras que por sus características particulares y sus pequeñas dimensiones, se encuentran más expuestas a posibles robos. Son muchas y es imposible su enumeración. De la tipología de pintura de caballete, merecen destacarse los lienzos de San Juan Bautista niño y Niño Jesús pasionario-buen pastor de la Iglesia de Nuestra Señora del Rosario, de Martín de la Jara. Asimismo, las esculturitas de San José y Santa Teresa de la capilla de Nuestra Señora del Rosario de San Juan de Aznalfarache o el magnífico crucificado del XVIII y realizado en barro cocido de la ermita del Santo Cristo de la Sangre, de Pedrera.

Son pocas estas páginas para describir y señalar la variedad y riqueza de los bienes muebles que se conservan en las ermitas, capillas y pequeñas iglesias de la provincia de Sevilla. Sin embargo, como se apuntaba al comienzo del trabajo, éste se planteaba simplemente para llamar la atención sobre el desconocimiento y la desprotección de los mismos. En este aspecto, debería ser la administración, con los medios legales que tiene, la que se encargara de tomar las primeras medidas de conservación y protección de los mismos. Pero, quizás más interesante y beneficiosa sería la labor de los Ayuntamientos, responsables, al fin y al cabo, del patrimonio local 17. Su labor podría estar encaminada, no sólo al conocimiento y difusión de estos bienes, sino también a tomar unas precarias medidas de salvaguarda de los mismos. En la primera línea de actuación, en cualquiera de las poblaciones existen licenciados en historia, y más concretamente en historia del arte, que a través de becas, subvenciones o de cualquier otro tipo de ayuda, pueden realizar los trabajos de investigación y estudio. El resultado de los mismos podría ser un primer acercamiento del resto de la población a la valoración de estos bienes a través de publicaciones o exposiciones. Un importante avance sería, como se ha realizado en Alcalá de Guadaira, la incorporación a la plantilla del área de cultura de una persona encargada de valorar, potenciar y gestionar los recursos turísticos que tiene la población. En el segundo de los aspectos, además de incluir estos edificios en los catálogos de protección de las normas urbanísticas, la realización de pequeñas obras de mantenimiento en estos edificios evitaría la pérdida y los posibles desastres. Obras de 
mínima cuantía como el retejado de los inmuebles, su encalado tanto exterior como interior, la renovación de las instalaciones eléctricas, por lo general, antiguas y obsoletas, o dotarlos de unas mínimas medidas de seguridad, conllevarían a una revalorización y perdurabilidad de estos edificios y su patrimonio.

Pero las autoridades locales o autonómicas no son los únicos responsables de este tipo de patrimonio. La mayoría de estos edificios son propiedad de la iglesia, por lo que sobre ella recae la máxima responsabilidad como queda recogido en la legislación nacional y autonómica ${ }^{18}$. No solo quedan obligados por la norma- tiva civil sino también por la religiosa, ya que les obliga a "la limpieza y pulcritud que convienen a la casa de Dios" y a que "deben emplearse los cuidados ordinarios de conservación y las oportunas medidas de seguridad" 19 . Esta misma responsabilidad debe ser compartida con las hermandades y cofradías que en muchas ocasiones se encuentran como depositaria de estos inmuebles en los que tiene las sedes.

Esperemos que entre todos consigamos revalorizar y proteger estos bienes que, al fin y al cabo no nos pertenecen, ya que sus verdaderos poseedores son las generaciones futuras.

\section{Notas}

I. HERNÁNDEZ NÚÑEZ, J.C: "Sistema de información del Patrimonio Histórico Andaluz : bases de datos de bienes muebles: el Inventario de las ermitas de la provincia de Sevilla", en Boletín del Instituto Andaluz del Patrimonio Histórico, n. 25, diciembre 1998. Págs. 204-205.

2. Diccionario de la Real Academia Española.

3. CÓDIGO de Derecho Canónigo, I3ª ed., Madrid, Biblioteca de Autores Cristianos, 1995. Canon, 1230.

4. Véase, Ídem. Cánones, 1226-1229.

5. IGUACEN BORAU, D.: Diccionario del Patrimonio Cultural de la Iglesia. Madrid, I99I, pág. 244. La capilla, al ser una iglesia, ha de presentar las características y necesidades que se recogen en los cánones 1214-1222.

6. REAL ACADEMIA ESPAÑOLA: Diccionario de Autoridades, Ed. Facs. Madrid, 1937; Madrid, 1969. Covarrubias también recoge una definición similar, "...pequeño receptáculo con un apartado a modo de oratorio y capillita para orar y un estrecho rincón para recogerse el que vive en ella, al que llamanos ermitaño...". COVARRUBIAS HOROZCO, S. de y RIQUER, M. de: Tesoro de la lengua española o castellana. Madrid, 1979

7. ISIDORO, SANTO, ARZOBISPO DE SEVILLA: Etimologías. $2^{\mathrm{a}}$ ed. Madrid, 1993. Pág. 683.

8. ALDEA VAQUERO, Q., MARIN MARTÍNEZ, T. y VIVES GATELL, J:: Diccionario de historia eclesiástica de España. Madrid, 1972-1987.

9. Tanto de las ermitas como de los eremitorios cordobeses existen gran volumen de estudios e interesantes trabajos, entre ellos, FERREIRA, J.M.: Las ermitas de Córdoba. Córdoba, 1993. VÁZQUEZ LESMES, J. R.: La devoción popular en sus ermitas y santuarios. Córdoba, 1986. MORENO CRIADO, Ricardo: Las ermitas de Córdoba, Cádiz, 1944. GUTIÉRREZ DE LOS RÍOS Y PAREJA OBREGÓN, M., Marqués de las Escalonias: Memorias que se conservan de alounos ermitaños que ha existido en la Sierra de Córdoba desde los tiempos más remotos hasta nuestros días e historia de la actual Congregación de Nuestra Señora de Belén. Córdoba, |9|1.

10. A este respecto consúltese, DÍAZ Y DÍAZ, M.: "El eremitismo en la España visigoda". Revista de dialectología y tradiciones populares, $n^{\circ} 6$, 1955, págs. 217-237. No existen estudios de ámbito general sobre el tema, los trabajos realizados hasta el momento se dedican a analizar "eremitorios" individuales o el desarrollo que tuvieron en algunas provincias. Una buena idea de la repercusión que este movimiento tuvo en España, a pesar de lo antiguo de la publicación, puede ser, ESPAÑA eremítica: actas de la VI semana de estudios monásticos, abadía de San Salvador de Leire, 15-20 de septiembre de 1963. Pamplona, 1970

I I. GUEDE, L.: Ermitas de Málaga. Málaga, 1987. Págs. 7-8. Dicho autor especifica que la obra fue publicada en Sevilla en 1672, sin embargo, los ejemplares que hemos localizado, en las bibliotecas Nacional de Madrid y Universitaria de Sevilla, aparece como fecha de edición la de 1674. Véase, SANTO TOMÁS, A. de: Constituciones synodales del Obispado de Málaga. Sevilla, Viuda de Nicolás Rodríguez, 1674. Queremos agradecer a Eduardo Asenjo el habernos facilitado la documentación sobre las ermitas malagueñas.

12. Sobre el patrimonio religioso destruido durante la Guerra Civil en estas poblaciones, puede consultarse HERNÁNDEZ DÍAZ, J. y SANCHO CORBACHO, A.: Edificios religiosos y objetos de culto saqueados y destruídos por los marxistas en los pueblos de la provincia de Sevilla. Sevilla, 1937.

13. BUZÓN FERNÁNDEZ, M.: La ermita de San Mateo : un monumento del siglo XIII, abandonado, recuperado para el pueblo de Carmona. Carmona, 1986.

14. "En los santuarios o en lugares adyacentes, consérvese visiblemente y custodiense con seguridad los exvotos de arte popular y de piedad". Código de Derecho Canónico, I3 a ed. Madrid,1995. Canon, 1234,2. A éstos se le ha de buscar un sitio idóneo dentro de los templos para su colocación, teniendo en cuenta de que no deben invadir el lugar en el que se encuentra la imagen devocional ni el ámbito de las iglesias. Asimismo, se recomienda a los encargados de los santuarios el educar el "buen gusto" de los fieles para que los exvotos que se ofrezcan sean dignos y no expresiones populacheras y de mal gusto. A este respecto vease las recomendaciones dadas por la CONGREGACIÓN para el Culto Divino, Orientaciones y sugerencias para el Año Mariano, 1987, págs. 58-59.

15. Sirvan de ejemplos, para el ámbito andaluz, los estudios realizados por VÁZQUEZ SOTO, J.M.: Exvotos de Andalucía: milagros y promesas en la religiosidad popular. Sevilla, 1980 y PÉREZ MUÑOZ, S.: Exvotos marineros de la provincia de Cádiz, Cádiz, 1991. Entre las exposiciones destacamos: Exvotos de Andalucía. Sevilla, Convento de Santa Inés, noviembre, 1982.

16. HALCÓN, F., HERRERA, F. y RECIO, A.: El retablo barroco sevillano. Sevilla, 2000. Págs. 422-423.

17. Ley 16/1985, de 25 de junio, del Patrimonio Histórico Español. Art. 7 y Ley 1//991, de 3 de julio, de Patrimonio Histórico de Andalucía. Art.4.

18. Ley 16/1985, de 25 de junio, del Patrimonio Histórico Español. Art. 36.I; Ley I/199I, de 3 de julio, de Patrimonio Histórico de Andalucía. Art. I5. I; Decreto 19/1995, de 7 de febrero, por el que se aprueba el reglamento de protección y fomento del Patrimonio Histórico de Andalucía. Art. 20. Además, véase, Real Decreto Legislativo 171992, de 26 de junio, texto refundido de la Ley sobre el Régimen del Suelo y Ordenación Urbana. Art. 20.

19. CÓDIGO..., ob. cit. canón I220. Además véase, SACRA CONGREGATIO CLERI, Circular Opera artis del I I de abril de 1971. 